講座 日臨麻会誌 Vol.38 No.7, 836 842, 2018

\title{
酸素運搬能を維持するために 一産科危機的出血への対応一
}

田中克明*

[要旨] 酸素運搬能は心拍出量, 酸素飽和度, ヘモグロビン值, 動脈血酸素分圧の4因子で規定さ れる. しかし，これらを連続的かつ正確にモニターできる機器の開発・普及は途上にあり，急激な 経過をとり得る産科危機的出血の病態評価において, 沉診療科的に使える段階にはない. 産科危機 的出血への対応指針ではショックインデックス(SI)が病態評価基準である. 特にSI 1.0, 1.5 は 臨床判断上の分水嶺である. 妊産婦では通常, 心機能・呼吸機能が大きくは障害されていないため に, 酸素運搬能維持のために最も重要となるのはへモグロビン值の維持である. そのためには迅速 な輸血の供給体制構築と安全・確実な輸血の投与が必要である.

キーワード : 産科大量出血, 酸素運搬能, 輸血

\section{はじめに}

2017 年に産科危機的出血への対応ガイドライン ${ }^{1)}$ が改訂され「産科危機的出血への対応指針 2017$\lrcorner^{2)}$ として発表された。本稿では産科大量出血症例にお いて酸素運搬能を維持する上で重要なモニタリング と輸血について述べる。その過程で関連するガイド ラインの要点を述べる。 また, 前回ガイドラインか らの変更点, ガイドラインに記載されていないが知 つておいたほうが良いと思われる事項についても概 説する.

\section{I＼cjkstart酸素運搬能とは}

狭義に考えれば, 酸素運搬能は, 酸素解離曲線で 示されるへモグロビンの酸素結合率の組織間格差で あるが，産科出血において問題となるのはよりマク ロな視点によるパラメー夕, すなわち酸素運搬量で
あろうと考えられるので，以下，これに関して述べ る.

酸素運搬量 $\left(\mathrm{DaO}_{2}\right.$ : oxygen delivery) は下式(1)で 表される。

(1) $\mathrm{DaO}_{2}=$ 心拍出量 $(\mathrm{CO}:$ cardiac output $) \times$ 動 脈血酸素含量 $\left(\mathrm{CaO}_{2}:\right.$ oxygen content $)$

$\mathrm{CaO}_{2}$ は下式(2)で表される。

(2) $\mathrm{CaO}_{2}(\mathrm{~mL} / \mathrm{dL})=1.34 \times$ ヘモグロビン $(\mathrm{Hb})$ 量 $(\mathrm{g} / \mathrm{dL}) \times$ 動脈血酸素飽和度 $\left(\mathrm{SaO}_{2}\right)+0.0031$ $\times$ 動脈血酸素分圧 $\left(\mathrm{PaO}_{2}\right)$

式(1)と式(2)より， $\mathrm{DaO}_{2}$ は最終的に下式となる.

(3) $\mathrm{DaO}_{2}=\mathrm{CO} \times\left(1.34 \times \mathrm{Hb} \times \mathrm{SaO}_{2}+0.0031 \times\right.$ $\left.\mathrm{PaO}_{2}\right)$

大量出血が想定される産科麻酔時においては, $\mathrm{DaO}_{2}$ が正確にリアルタイムでモニターできれば理 想的である。上式の変数 $\mathrm{CO}, \mathrm{Hb}, \mathrm{SaO}_{2}, \mathrm{PaO}_{2}$ の うち, $\mathrm{PaO}_{2}$ の酸素運搬量への寄与は小さいので重 
要となるのは $\mathrm{CO}, \mathrm{Hb}, \mathrm{SaO}_{2}$ である。これらのうち, $\mathrm{SaO}_{2}$ は連続モニタリングにおいて正確性と即時性 が確立されている経皮的動脈血酸素飽和度 $\mathrm{SpO}_{2}$ で 代用できると考えられるが，CO と Hbに関しては 連続モニタリングにおける正確性と即時性が確立さ れているとは言えない. COの測定手段のゴールド スタンダードは肺動脈カテーテルだが，一般的に用 いられる連続心拍出量測定には 5 分から 15 分の遅延 がある ${ }^{3), 4)}$. CO に関しては即時性において肺動脈力 テーテルよりも優れる低侵襲連続心拍出量モニター がわが国では普及しており ${ }^{5)}$ ，とりわけ最も普及し ている Vigileo ${ }^{\mathrm{TM}}-$ FloTrac $^{\mathrm{TM}}$ システムは近年, 正確性

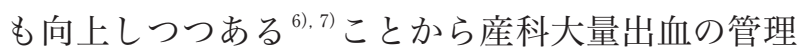
に有用かもしれない. $\mathrm{Hb}$ に関しては経皮的に值を 連続モニタリングできる機器 (Masimo 社, $\mathrm{SpHb}^{\circledR}$ ) が近年臨床使用可能となり, 帝王切開における使用 も検討されたが，まだ実測值と満足できる一致を見 ていない ${ }^{8)}$. $\mathrm{CO}$ と $\mathrm{Hb}$ は非侵襲的連続測定を開発し た企業が異なるため，これらから算出されるパラメ ータである $\mathrm{DaO}_{2}$ の連続モニタリングも当面は臨床 使用できる状況とはならないと思われる。

産科危機的出血への対応指針においては, 初版か ら循環血液量の評価指標としてショックインデック スが採用されている(下式).

ショックインデックス $(\mathrm{SI})=$ 心拍数/収縮期血圧 標準モニターのみで算出でき, SI=1で約 $1.5 \mathrm{~L} の$ 出血, $\mathrm{SI}=1.5$ で $2.5 \mathrm{~L}$ の出血と推測出血量も対応指 針に記載されていることから，フローチャート上で 迷いが生じにくい. SI $\geqq 1$ で分娩時異常出血と認識 し, SI $\geqq 1.5$ で産科危機的出血を宣言して直ちに輸 血を開始せねばならない。

$\mathrm{PaO}_{2}$ の酸素運搬量への寄与は小さいと既に述べ たが，貧血時は無視できない，仮に貧血産婦を純酸 素投与下で挿管人工呼吸管理とした場合，例えば $\mathrm{Hb}=5 \mathrm{~g} / \mathrm{dL}, \mathrm{PaO}_{2}=400 \mathrm{mmHg}$ であれば, $\mathrm{SaO}_{2}=$ 100 となるので, (2)式ではへモグロビン結合酸素は $67(\mathrm{~mL} / \mathrm{dL})$, 溶存酸素は $12.4(\mathrm{~mL} / \mathrm{dL})$ となる。す

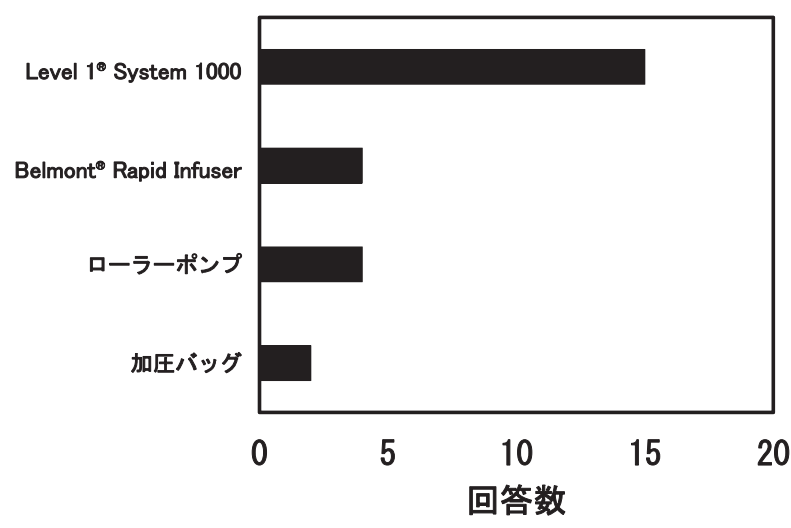

図1 輸血回路の使用割合

SNS「Facebook」の非公開グループ「麻酔予備校」 のアンケートょり。「癒着前置胎盤で, $5,000 \mathrm{~mL}$ 以上 の出血可能性が強い場合, 麻酔科でできることとし て何を準備されますか?」という問いに対してメンバ 一数 170 名のうち回答者 32 名. 複数回答あり。アン ケートの選択肢から輸血回路に関連するもののみを 抽出してグラフを作成した。

なわち, $\mathrm{PaO}_{2}$ の寄与は $\mathrm{CaO}_{2}$ の $15 \%$ を占める. 2017 年改訂の産科危機的出血への対応指針から母体への 酸素投与が記載されたことは上式を鑑みても意味の あることである。

\section{II 大量輸血装置について}

危機的出血への対応ガイドライン ${ }^{9)}$ 策定以降，口 ーラーポンプ式の大量輸血装置は非承認となった が，筆者の知る限りにおいては，いまだにローラー ポンプ式の大量輸血装置を用いている施設はある (図1)。それ以外にいわゆる用手ポンピングに頼っ ている施設も数多くあり, 輸血時のトラブルは相当 発生しているものと推測される(図2)。当施設にお いて用いられている大量輸血装置の一覧を図に示す (図3)。多くの大量輸血装置は仕様上 $300 \mathrm{~mL} / \mathrm{min}$ の速度で輸血が可能，となっているが，通常麻酔科 医が手術時に確保する静脈路は細く，この速度での 輸血は現実には困難である。例えば，当施設で用い ているローラーポンプ式輸液装置と輸液・輸血回路,

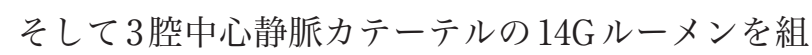




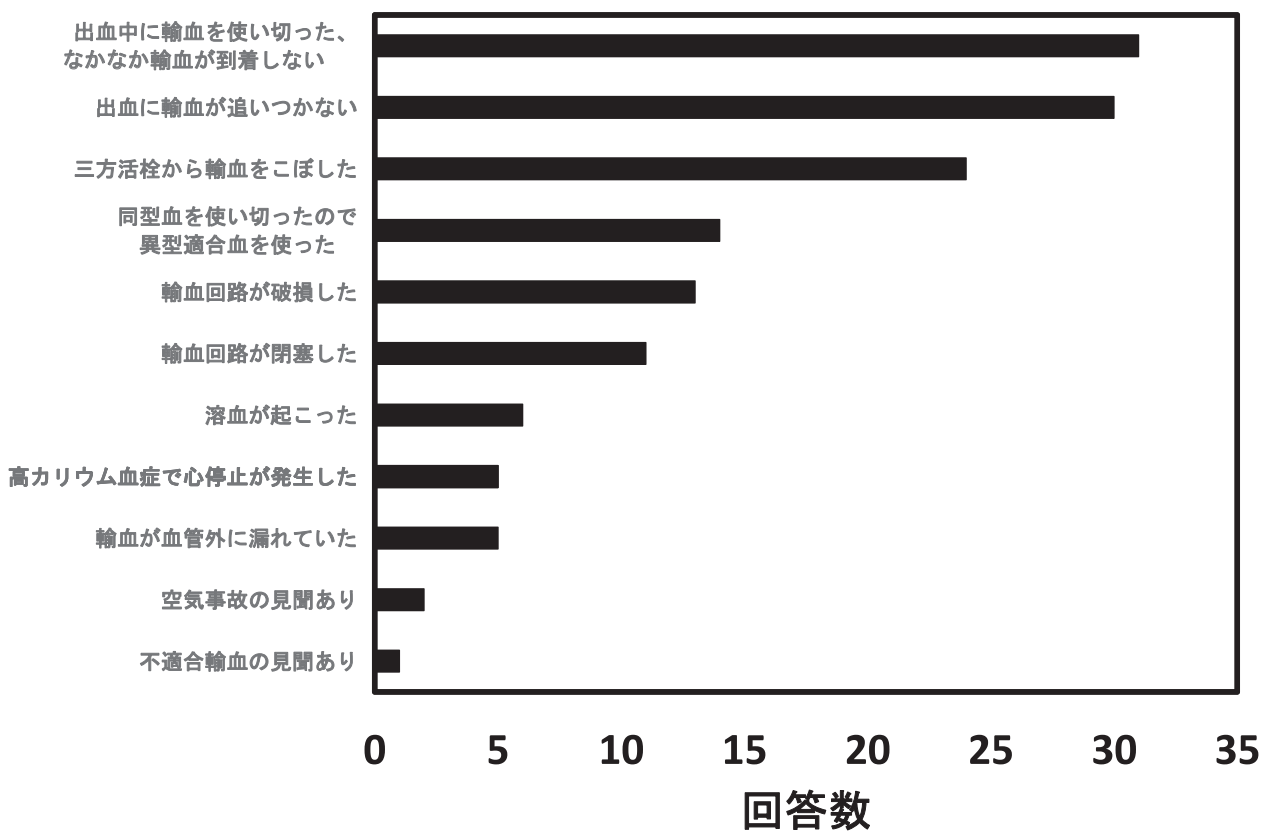

図2＼cjkstart輸血時のトラブル経験割合

SNS「Facebook」の非公開グループ「麻酔予備校」のアンケートより。メンバー数 170 名 に対して回答者 31 名. 複数回答あり。アンケートの選択肢は掲載用に元の文意を損なわな い範囲で改変した。
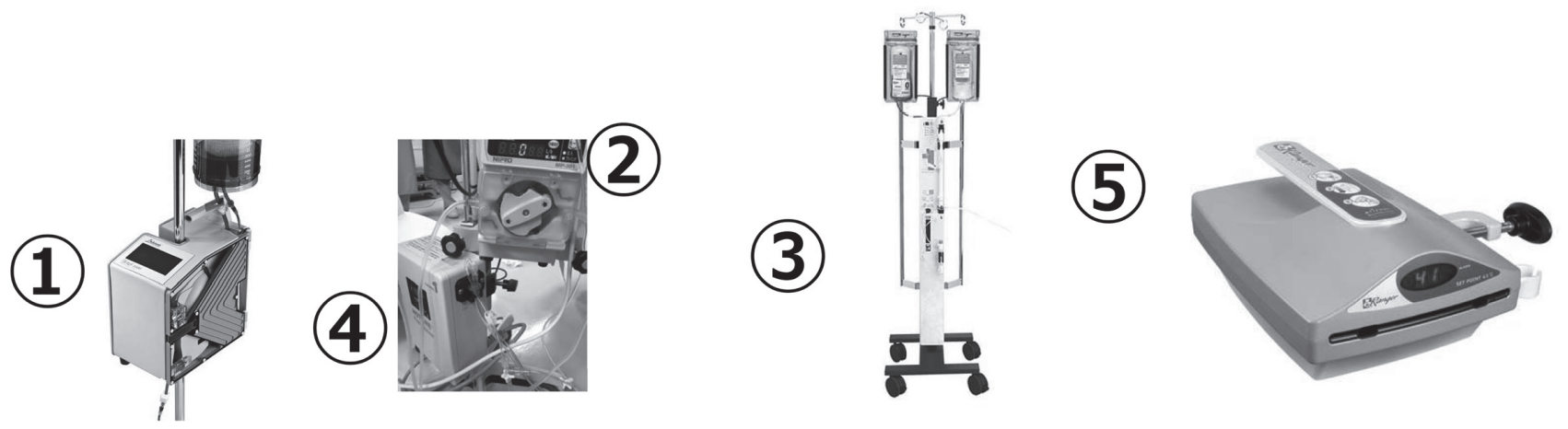

\begin{tabular}{|c|c|c|c|c|c|c|c|}
\hline & & $\begin{array}{l}\text { 強制輸液可否 } \\
\text { (回路内圧無視) }\end{array}$ & 最大輸液速度 & $\begin{array}{l}\text { 気泡 } \\
\text { センサー }\end{array}$ & $\begin{array}{l}\text { 回路内圧 } \\
\text { センサー }\end{array}$ & 気泡除去 & 加温効率 \\
\hline (1) & Belmont $^{\oplus}$ Rapid Infuser & $x$ & $1000 \mathrm{~mL} / \mathrm{min}$ & 有 & $\bigcirc$ & () & () \\
\hline (2) & 補液ポンプ MP301 & $\bigcirc$ & $300 \mathrm{~mL} / \mathrm{min}$ & 有 & $\times$ & $\times$ & $\times$ \\
\hline (3) & Level $1^{\circledR}$ System 1000 & $x$ & $500 \mathrm{~mL} / \mathrm{min}$ & $\begin{array}{l}\text { 無 } \\
\end{array}$ & $x$ & 0 & () \\
\hline (4) & Level $1^{\oplus}$ HotLine & $x$ & $\times$ & $x$ & $x$ & $\bigcirc$ & () \\
\hline (5) & Ranger $^{\mathrm{TM}}$ & $x$ & $x$ & $x$ & $x$ & 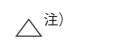 & O \\
\hline (6) & 人カポンピング & 0 & $>200 \mathrm{~mL} / \mathrm{min} ?$ & $\triangle$ & $\triangle$ & $\triangle$ & $\times$ \\
\hline
\end{tabular}

図3 大量輸液・輸血システムの比較

( ) : 最も優孔ている, $\bigcirc$ : 優孔ている, $\triangle$ : 環境に依存する, ないしは欠点あり, $\times$ : 当該機能が存在しない

注)単なるドリップチャンバーであるため, 大量の空気混入には対応できない. 
み合わせて, 実際に赤血球濃厚液 (以下 $\mathrm{RBC}$ 液)を接 続して回路内圧を実測した場合, 輸注速度が $60 \mathrm{~mL} /$ minを越えると回路内压が $300 \mathrm{mmHg}$ を越えた。 $300 \mathrm{mmHg}$ は溶血を生じない上限圧 ${ }^{10)}$ であるととも に, 多くの輸液・輸血回路の仕様上の上限圧でもあ り，これを越えると輸液・輸血回路破損の危険が高 まる。実際に某社の加温装置では複数台の破損例が あった。機器内が血液污染された場合, 洗浄困難で あるために修理不能すなわち全損となってしまう製 品もあるので購入時に注意を要する。性能面では Belmont ${ }^{\circledR}$ Rapid Infuserが最も優れているが，日本 での発売が最近であることと価格面の問題もあり, 普及が進んでいない，結局のところ， $300 \mathrm{~mL} / \mathrm{min}$ の流量を得るには, 仕様上, その流量での使用が保 証されている透析用ブラッドアクセスに大量輸血装 置を接続するのが確実である。しかしながら，2000 年前後から三方活栓経由の感染予防のために閉鎖式 点滴回路が用いられるようになり, 多くの手術室も その例外ではなくなった。この閉鎖式回路は各社か ら多種の製品が販売されているが，大量輸血に好適 なものは筆者の知るかぎり絶無である。しかし, 大 量出血が予期し得女ものであった場合は, 細径の留 置針と閉鎖式回路の組み合わせのどこかに上述の大 量輸血装置のいずれかを組み入れて輸血を開始せざ るを得ないこともある。現状大半の施設で用いられ ている大量輸血回路には回路内圧モニターが内蔵さ れていないが，これに関してはモニターの圧ライン を大量輸血装置より下流の回路側管に接続すること で解決できる。こうすることによって回路内圧の波 形が常時モニターに表示されるようになり，回路内 圧の上昇や回路の停止, 気泡混入 (回路内圧の低下 や陰圧が発生する)が判別しやすくなる(図4)。

\section{III＼cjkstart高カリウム血症について}

産科危機的出血への対応指針上は輸血中の高カリ ウム血症に関して注意すべきとの記載はあるもの の，具体的な回避策，対応策の記載はないので以下

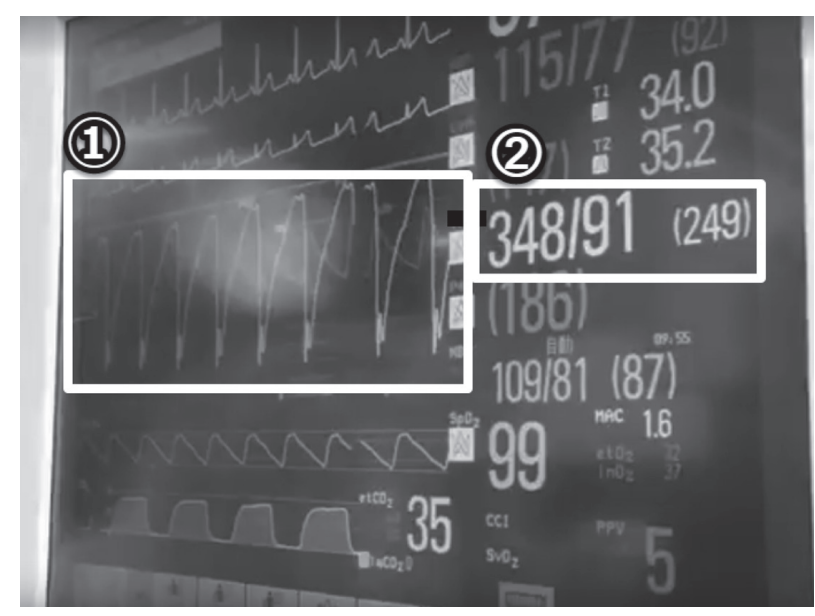

図4 ポンピング中の輸血回路内圧モニタリング

圧ラインを補液ポンプMP301 と加温システム Level $1^{\mathbb{R}}$ Hotlineの間の三方活栓に接続し，回路内圧波形(1) と数值(2) とをモニターに表示させている.内径 $14 \mathrm{G}$ の中心静脈カテーテルを用いても， RBC液の場合, ローラーポンプ流量が $60 \mathrm{~mL} / \mathrm{min}$ を越えると回路内 圧 $300 \mathrm{mmHg}$ を越元る。

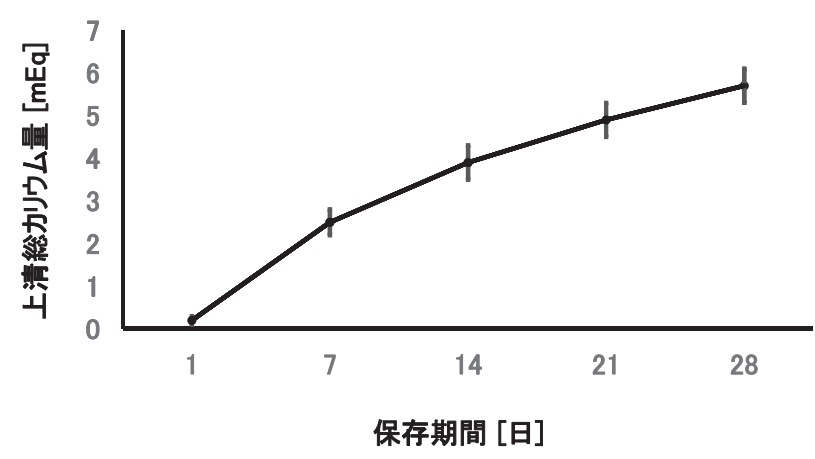

図 5 放射線照射後RBC 中のカリウム量

〔日本赤十字: 赤血球濃厚液-LR「日赤」の安定性試験成 績.〈http://jrc.or.jp/vcms_lf/iyakuhin_seihin090317-13. pdf〉P.6の図を引用・改変]

に概説する，RBC液に含まれるカリウムの含量は放 射線照射後の期間に大きく依存する．照射後の期間 が 1 週間で $\mathrm{RBC}$ 液 2 単位製剂 1 パック当たり $2 \mathrm{mEq}$,

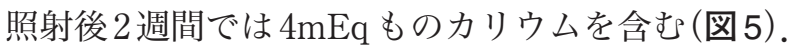
日本輸血・細胞治療学会による，血液製剂を使用し た施設を全対象とした調查(10,211施設，調查票回 収率 $51.52 \%)$ においては, 2015 年に合計 4,734,062 単 
位の赤血球製剤が購入され，このうち未照射の製剤 は80,632 単位(1.7\%)であった。すなわち血液セン夕 一で照射済みの赤血球製剂の使用率は $98.3 \%$ てっっ た ${ }^{11)}$. 出荷時点で照射後数日経過し, 出荷先でも数 日保管されるので照射済み $\mathrm{RBC}$ 液には少なからぬ カリウムが含有されうる. 現行の大量輸血装置は仕 様上, 1 分間に 1 パックの輸注が可能である.例えば, 当施設での $\mathrm{RBC}$ 液の照射から投与までの期間は大 半が 1 ～週間であるため，この速度で輸注するこ とは塩化カリウムを毎分 $1 \mathrm{mEq}$ 以上ずつボーラス静 注していることとほぼ変わりがない。 カリウム除去 フィルターを使用することにより， RBC 液中のカ リウムの大半を除去することは可能であるが，フィ ルター部分の流量抵抗が高いために自然滴下速度が 遅い.しかもポンピングとの併用は禁じられている. また，フィルターはある程度カリウムを吸着すると カリウム吸着効率が落ちるため, $\mathrm{RBC}$ 液 2 パックご とに交換せねばならない ${ }^{12}$.

\section{IV セルサルベージ(Cell Saver $\left.{ }^{\circledR}\right)$ につて}

元来, セルサルベージの適応は清潔手術であるた め, 污染手術である帝王切開などの産科出血時の使 用はオフラベル使用である。産科危機的出血への対 応指針にも記載はない。しかし，血液製剤の迅速な 確保が困難で大量出血が予想される，ないしは現に 起こっている場合は有力な同種血輸血回避ないしは 節約手段となり得る。また回収血は生理食塩水で洗 浄され, 濃縮されるために投与時はカリウム含量が 極女て低く, 保存血輸血時に問題となる高カリウム 血症のリスクを回避できることもメリットである. 懸念されるリスクは回収血への細菌, 羊水成分, 胎児 赤血球の混入であるが，そのリスクはごく低い ${ }^{13)}$, 14). 実際に産科領域でセルサルベージは総計 670 例以上 の使用報告があるが，この中に明らかな因果関係を 伴った有害事象報告はない ${ }^{15)}$. しかし, 使用の前提 となる白血球除去フィルターは回路抵抗が高いため に輸注速度が遅い。そして, 胎児成分の除去効率に
最も優れる白血球除去フィルター $\left(\right.$ LeukoGuard $\left.^{\circledR} \mathrm{RS}\right)$ が本邦未承認であるなどの問題が残されている.

\section{V ヘモグロビンの輸血トリガー}

米国血液銀行協会の一般患者を対象としたガイド ラインでは，へモグロビン值 $7 \mathrm{~g} / \mathrm{dL}$ が従来の $10 / 30$ ruleすなわちへモグロビン值 $10 \mathrm{~g} / \mathrm{dL}$ よりも妥当で ある ${ }^{16)}$ との推奨がなされた。また，英国王立産婦人 科協会のガイドライン 2015 においても同様の推奨 がなされている ${ }^{17)}$ 。しかし，日本人女性は貧血の割 合が高く ${ }^{18}$ 妊娠により生理的貧血もきたすので, こ れらのガイドラインを適用することには慎重を期さ ねばならない，直近の産科危機的出血への対応指針 においては，前回同様，輸血開始基準となるへモグ ロビンのトリガー值記載は見送られたが，日常臨床 においてはトリガー值を求める声は強い。本シンポ ジウムにおいては，へモグロビン $5 \mathrm{~g} / \mathrm{dL}$ 前後をト リガー值として考えてもよいのではないかという意 見が出された，同值を安全限界とする expert opinion もある ${ }^{19)}$ が今後のさらなる検討が望まれる。

\section{MTPについて}

産科危機的出血への対応指針には初版から緊急時 の異型適合血使用が明記されている ${ }^{1)}$ 2)。 また，外 傷救急の領域において提唱された massive transfusion protocol(MTP)の概念を産科領域において適 用することも論ぜられるようになった ${ }^{20)}$ 。当施設は 三次救急施設であり，2015年より MTPにのつとつ た血液供給体制が整備済みである(図6)。対象は外 傷患者に限定していないので，産科患者も含められ る。輸血搬送時のマンパワー確保のために非医療従 事者も人員に含まれている。重要なことは，各施設 のリソースの実情に応じた MTPを構築することで ある。

\section{まとめ}

産科大量出血における，酸素運搬能の評価と維持 


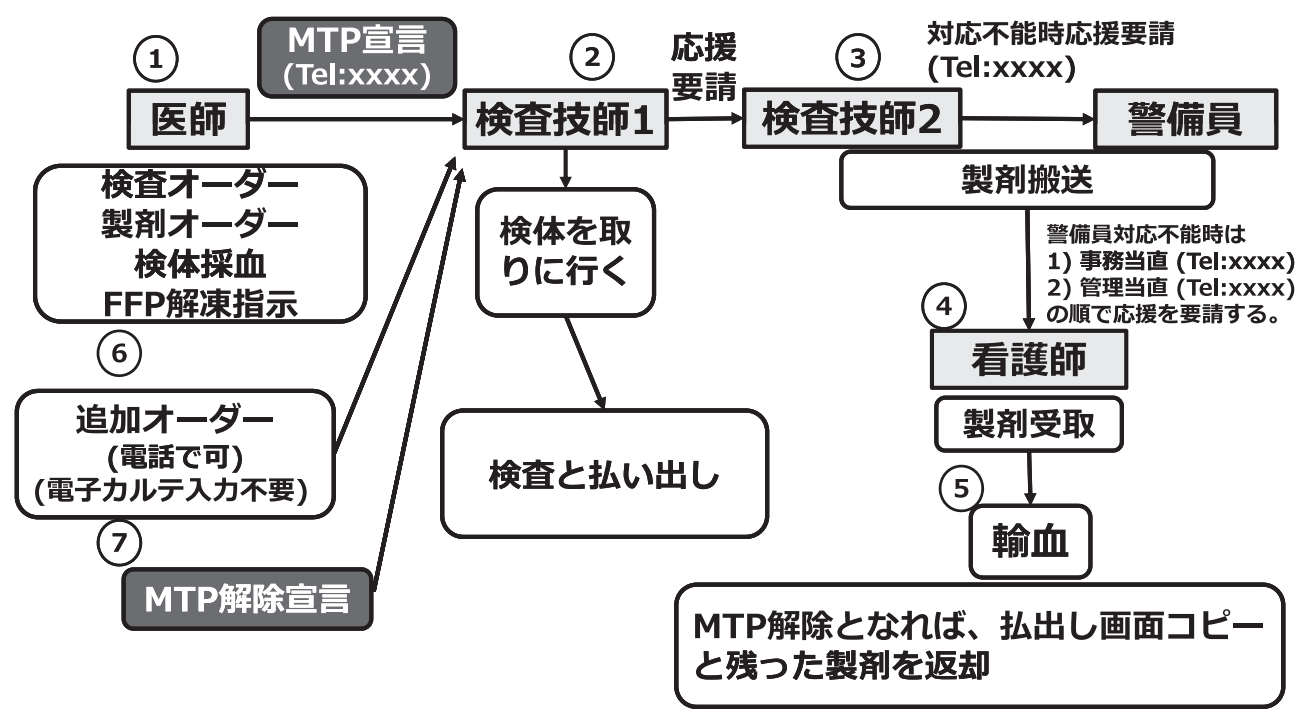

図6 大阪市立大学医学部附属病院の MTP プロトコール

について概説し，産科危機的出血への対応指針の関 連部分について解説した。 大量出血に対しては大量 輸血が必要となるが，大量輸血装置，輸血回路には 現状，解決すべき課題が多い。これに対して紙数の 許す限りの解決策を提示した。また，大量輸血の際 に問題となる高カリウム血症についても概説した。 Cell Saver ${ }^{\circledR}$ の使用に関しては適切なフィルターが 使えない現状を強調しておきたい，MTPに関して は通常の輸血手順をバイパスするため, 速度と安全 性を可及的に両立したプロトコールを各施設におい て策定していく必要がある。

本稿は, 日本臨床麻酔学会第 36 回大会 $(2016$ 年, 高知市)におけるシンポジウム (14)「産科出血時の 輸血戦略：ポンピングよりもプランニング」に，加 筆したものです。本稿執筆にあたり，アンケートに 回答していただいた Facebookの非公開グループ 「麻酔予備校 : https://www.facebook.com/groups/ anesthprepschool/」のメンバーに深甚の謝意を表 します。

\section{参考文献}

1）日本麻酔科学会, 日本輸血・細胞治療学会ほか：産科

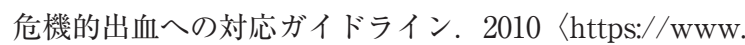
jspnm.com/topics/data/topics100414.pdf〉(2018.8.24閲 覧)

2）日本産婦人科学会，日本産婦人科医会，日本周産期・新 生児医学会ほか：産科危機的出血への対応指針 2017. 2017 〈http://www.anesth.or.jp/guide/pdf/guideline_ Sanka_kiki.pdf〉 (2018.8.24閲覧)

3) Siegel LC, Hennessy MM, Pearl RG : Delayed time response of the continuous cardiac output pulmonary artery catheter. Anesth Analg $83: 1173-1177,1996$

4) Aranda M, Mihm FG, Garrett S, et al. : Continuous cardiac output catheters : delay in in vitro response time after controlled flow changes. Anesthesiology $89: 1592-1595,1998$

5) Suehiro K, Tanaka K, Mukai A, et al. : Hemodynamic monitoring and management in high-risk surgery : a survey among Japanese anesthesiologists. J Anesth $30: 526-529,2016$

6) Suehiro K, Tanaka K, Mikawa M, et al. : Improved Performance of the Fourth-Generation FloTrac/Vigileo System for Tracking Cardiac Output Changes. J Cardiothorac Vasc Anesth 29:656-662, 2015

7) Suehiro K, Tanaka K, Funao T, et al. : Systemic vascular resistance has an impact on the reliability of the Vigileo-FloTrac system in measuring cardiac output and tracking cardiac output changes. Br J Anaesth 
$111: 170-177,2013$

8) Butwick A, Hilton G, Carvalho B : Non-invasive haemoglobin measurement in patients undergoing elective Caesarean section. Br J Anaesth 108 : 271-277, 2012

9）日本麻酔科学会, 日本輸血・細胞治療学会ほか: 危機的 出血への対応ガイドライン. 2007 〈http://www.anesth. or.jp/guide/pdf/kikitekiGL2.pdf〉 (2018.8.24 閲覧)

10) Frelich R, Ellis $\mathrm{MH}$ : The effect of external pressure, catheter gauge, and storage time on hemolysis in $\mathrm{RBC}$ transfusion. Transfusion $41: 799-802,2001$

11）日本輸血・細胞治療学会 : 平成 27 年度血液製剂使用実 態調査デー夕集. 2016

12) カワスミカリウム吸着フィルター(4単位以内用, 1 単 位以内用) 添付文書(第6版). 2016

13) Goucher H, Wong CA, Patel SK, et al. : Cell Salvage in Obstetrics. Anesth Analg 121 : 465-468, 2015

14）谷口美づき, 中島芳樹: 産科領域におけるセルサルベ ージ. 日本臨床麻酔学会誌 $35: 244-249,2015$
15) Allam J, Cox M, Yentis SM : Cell salvage in obstetrics. Int J Obstet Anesth $17: 37-45,2008$

16) Carson JL, Guyatt G, Heddle NM, et al. : Clinical Practice Guidelines From the AABB : Red Blood Cell Transfusion Thresholds and Storage. JAMA 316 : 2025-2035, 2016

17) Royal College of Obstetricians \& Gynaecologists : Blood Transfusion in Obstetrics (Green-top Guideline No.47). 2015

18) Kusumi E, Shoji M, Endou S, et al. : Prevalence of anemia among healthy women in 2 metropolitan areas of Japan. Int J Hematol $84: 217-219,2006$

19）渡邊直英, 半田誠：診療の実際 緊急大量出血時の輸血 一輸血の実際, マッチングなど(特集 貧血を診る)。綜 合臨床 $58: 1797-1801,2009$

20) Butwick AJ, Goodnough LT : Transfusion and coagulation management in major obstetric hemorrhage. Curr Opin Anaesthesiol 28 : 275-284, 2015

\title{
Maintenance of Oxygen Delivery
}

\author{
Katsuaki TANAKA \\ Department of Anesthesiology, Osaka City University Graduate School of Medicine
}

It is important to maintain oxygen content $\left(\mathrm{CaO}_{2}\right)$ when we manage maternal hemorrhage. $\mathrm{CaO}_{2}$ is a function of cardiac output, oxygen saturation, hemoglobin concentration, and arterial oxygen partial pressure. However, these parameters cannot be monitored continuously with precision. In "Guidelines for Management of Critical Bleeding in Obstetrics," the Shock Index (heart rate/systolic blood pressure) is recommended for evaluating maternal hemodynamics. Specifically, both "SI $\geqq 1.0$ " and "SI $\geqq 1.5$ ” are decision points for starting transfusion in the guidelines. Normally, cardiac and respiratory functions are not severely impaired in pregnant women, so it is crucial to maintain the hemoglobin level. It is therefore necessary to develop a rapid blood delivery system and provide blood products safely and reliably.

Key Words : Massive maternal hemorrhage, Oxygen delivery, Transfusion

The Journal of Japan Society for Clinical Anesthesia Vol.38 No.7, 2018 